\title{
PRELIMINARY CONTIRIBU'TION TO OUR KNOWLEDGE OF THE CRETACEOUS FORMATION ON LONG ISLAND AND EASTWARD.
}

\author{
[Plates V-VII.]
}

IY ARTHUR HOLLICK.

The assumption that cretaceous strata were to be found beneath a part of Staten Island and practically the whole of Long Island, except the small archacan area at its western end, has been recoguized as probable by nearly every geologist who has studied the region. The trend of the cretaceous strata in New Jersey and their stratigraphic relations to the crystalline and other rocks along their border, justified the assumption that the same conditions prevailed lortheastward, although there much modified by the forces which acted upon them during the quaternary age. The lithological characters wore also such that the similarity of the clays and sands of New Jersey, Staten Island and Long Island, was early recognized. So that stratigraphically and ljthologically the assumption seemed justified. Palæontologically, however, until within the past ten years or so, the indicutions were very meagre and unsatisfactory, and it has only been within that time that we can be said to have collected sufficient evidence to justify the positive declaration that the early assumption was correct. In regard to Staten Island the facts have already been publisined*. The facts relating to Long Island have been briefly mentioned on several occasions, notably at meetings of the Academy, and memoranda have appeared in print, but nowhere has any connected account been published. The object of this contribution is to present all the facts thus far known to the writer. New material is constantly coming to light, but it has been decilled to describe in advance some that is now available, in order to demonstrate the existence of cretaceous strata on Long Island beyond any further doubt, and thus to correct an erroneous impression which seems to be

* "Palkentology of the Cretaceous Formation on Staten Island." (Trans. N. Y. Acad. Sci. XI. 96-103) and "Additions to the Palxobotany of the Creticeous Formation on Staten Island." (Trans. N. Y. Acad. Sci. XII. 1-12,) 1892. 
entertained in certain quarters, that the evidence is still incomplete*.

Before describing the later discoveries, however, it has been thought advisable to give the following brief review of the observations which preceded them:

The earliest attempt at a differentiation of the later formations in the eastern United States, upon anything like a modern basis, was made about 1825 , and may be said to have begun with the studies of Lardner Vanuxem and S. G. Morton. The latter, in a paper read before the Philadelphin Academy of Natural Sciencest, divides the coast plain into Secondary, Tertiary and Alluvial, and speaks of Manbattan and Long Islands, Martha's Vinejard and Nantucket as being included within the Tertiary (the equivalent of the tertiary as we recognize it to-day). They were also the first to note the equivalence of the New Jersey strata with the cretaceous of the old worlda conclusion which was arrived at by the study and comparison of the fossil faunas.

In 1841, Sir Chas. Lyell visited this country, and in his subsequent contributions + be describes his visit to New Jersey and acknowledges the correctness of Morton's conclusions in comparing certain of the strata there with the European cretacecus. These papers, incomplete as they appear to us now, marked an epoch in our knowledge of the formations in question. The previous observations and speculations in regard to the age and structure of the strata composing the eastern border of our continent were exceedingly crude and chaotic, such as these of Samuel L. Mitchill§, in the early years of the present century, from which $I$ had occasion to quote in a former paper\|, and the same author subsequently furthur discusses the geology of the north shore of Long Island, in a communication to Archibald 1891.

* Bull. No, 82, U. S. G. S. Correlation Papers-Cretaceous. C. A. White.

p. 85. "Several persons have written upon, or referred to, the discovery of cretaceous fossils upon Long Island; but a large pronortion of these reported discoveries lack confrmation. Beyond the identification by Prof. Newberry of if few snecies of fossil plants which have been obtained at different localities along and near the north shore of the western portion of the island, the evidence of the existence of cretaceous deposits there is mostly or entirely conflned to the known or assumed trend of the cretaceous outcrop which has just been mentioned, and to lithological similarity of certain deposits there to those of portions of the non-marine division of the New Jersey cretaceous section."

$\dagger$ "Geological Observations on the Secondary, Tertiary and Alluvial Formations of the Atlantic Coast of the United States of America." (Journ. Acad. Nat. Sei. Phil. vi. Part i. 59-71 (1827).)

\# "Notes on the Cretaceous Strata of Now Jersey and Other Parts of the United States bordering the Atlantic." (Am. Journ. Sci. xlvii. 213-214 (1844) and Quart. Journ. Geol. Soc. London, i. 55-60 (1845).)

\$ Med. Repos. iii. 2d Ed. 325-335 and v. 212-215 (1805, 1802).

II Trans. N. Y. Acad. Sci. xji. 189-202 (1893). 
Bruce, dated July 4, 1811*, in which he criticises, William Misclure's geological map of the United Statest in so far as it relates to this region, and amends his former conclusions in regard to the "primitive" character of the rocks, regarding them all as "alluvial," except "the strata of granite and gneiss which occur at and near Hurlgate." He is largely led to these later conclusions by the discovery of clam, oyster and periwinkle shells and "carbonated wood" many feet below the surface in Brooklyn, New Utrecht, Flatbush, Newtown and Bushwick, in or below the Drift as we know it to-day. He continues: "I say nothing of the wood discovered sixty feet deep, a little to the eastward of Westbury Meeting-house; nor of the bark, and other parts of a tree, raised from the depth of forty feet at Eastwoods; because both these places are situated to the south of the barrier ridge, and are within the district allowed by all to be alluvial."

On July 15, 1823, John Finch read a paper before the Academy of Natural Sciences of Philadelphia, entitled "Geological Essay on the Tertiary Formation in America" $F$, in which he refers the Staten Island, Long Island, Raritan and Gay Head clays to the tertiary.

Shortly after this followed the researches of Vanuxem and Morton, previously mentioned, which really mark the beginning of our modern conceptions of the true relationships of the strata.

In 1837 and 1838, in the first reports of the geological survey of New York $\$$, mention is made of the clays and sands on Staten and Long Islands, but with only vague allusions to their probable geological relations-the deposit on Staten Island being supposed to be "similar in its general character to that of Cheesequake and Matavan Point, on the New Jersey shore, and it appears to have a similar geological position," while in regard to Long Island the contorted condition of the clay strata and the large amount of lignite contained in them are mentioned, and also that "they have the external characters of potters' clay," but they also are referred to the tertiary.

In the final report, published in 1843||, Mr. Mather arrives at

* Am. Min. Journ. i. 129-133 (1814).

$\dagger$ Trans. Am. Phil. Soc. vi. 411-428 (1809).

$\ddagger$ Am. Journ. Sci. vii. 31-43 (1824).

S Assembly Document No. 161. Communication from tho Governor [T. L. Marcy] relative to the geological survoy of the State. First Ann. Rent. 1st Geol, Dist. Wm. M. Mather (Feb. 11, 1837), and Assembly Document No. 200, Second Iiept. etc. (Fob. 20, 1838).

II Nat. Hist. N. Y. Part iv. Geology. Part i. comprising the Geology of the First Geological District. 
more definite conclusions in regard to the same strata, and under the heading "Upper Secondary System, I., Long Island Division:" says: "The reasons for believing that the principal mass of this formation is older than the Tertiary will be seen in tracing the equivalency of these beds to those of New Jersey, MIary]and, Delaware and Virginia, where it is considered as established that the corresponding strata belong to the upper secondary of the epoch of the cretaceous and greensand formations." So that stratigraphically and lithologically the true relationship between Long. Island and the rest of the Atlantic coastal plain was beginning to be appreciated. Tertiary and later fossils had been found on the island, but the palæontological evidence of its cretaceous strata was wanting. About this time a discovery was reported which caused considerable discussion, the echoes of which have been heard to within a few years ago. At the meeting of the New York Lyceum of Natural History on December 19, 1842, a specimen of Exogyr was shown, said to have been found in digging a well in Brook lyn. I quote as follows from the minutes of that meeting :"Dr. Jay exhibited a fossil Exogyra, found sixty feet below the surface, in digging a well in the city of Brooklyn. Referred to Messrs. Jay and W. C. Redfield to report upon the authenticity of the locality and other matters respecting the geological relations of the fossil." In the minutes of the meeting of January 9,1843 , the report of this committee is included, from which the following facts are abstracted: The fossil was found in 1834 by - and Newman, well-diggers, while excavating a well in Clark street, between Willow and Pineapple streets. It was taken by them to Mr. Smith, late Mayor of Brooklyn, who descended the well and examined personally the location where it was found, about sisty-five feet below the surface. The shell was said to have contained " a dark colored earth or residuum, differing from the earth in which the fossil was imbedded."

The discovery was again mentioned at the Albany meeting of the Association of American Geologists and Naturalists in 1843, by Mr. Redfield, who said: "This is believed to be the first authentic memorial of the cretaceous formation found in the State of New York." * It is also mentioned by Issachar Cozzens, Jr., who evidently considered it as significant, and who prophesies as follows :" $†$ "It is more than probable that this mem-

\footnotetext{
* Abstract of the proceedings, 4th session. Assn. Am. Geol. \& Nat.in Am. Journ. Sci. Xlv. 135-165 (1843). (1813).

† "Geological History of Manhattan or New York Island," etc., pp. 114
} 
ber of the Cretaceous Group [New Jersey Marl] underlies Long Island, and may be a continuation of the great range which begins at the south, in Virginia, and runs through New Jersey to the Neversink Hills, at which place it is last seen above the surface."

This same Exogyra is also quoted by several subsequent writers, long after it had lost its importance as an indication of the presence of cretaceous strata, by reason of the discovery of other indisputable cretaceous material in situ. The latest reference is by C. A. White*, who, following the early conclusions of E. D. Copet, had divided the eastern cretaceous strata into "marine" and "non-marine." He says: "All the admissible evidence of the present existence of cretaceous deposits upon Long Island relates to the non-marine division alone. If the reputed discovery of a specimen of Exogyra costata, Say, in digging a well near Brooklyn were satisfactorily confirmed, and it were shown to have been found in situ, the fact would be accepted as proof of the present existence there of at least a portion of the marine division."

The probable extension eastward and northward of the strata composing the coastal plain was noted by Edward Hitcheock in 1824, in a paper entitled "Notices on the Geology of Martha's Vineyard and the Illizabeth Islands " $\neq$, where he says :

"Long Island, in those places where I have seen it, is unquestionably very similar in its geological structure to Martba's Vineyard, and probably belongs to the same era. . . If we take [Maclure's] map, and prolong the line, or rather curve, that separates the alluvial tract . . from the primitive towards the northeast, we shall find that it passes between Martha's Vineyard and the continent . . leaving us to conclude that the Vineyard and Nantucket are the continuation of that extensive formation, hitherto called Alluvial, of which Long Island has been regarded the northeastern limit."

Subsequently, the same author notes the occurrence near Marshfield, Mass., of material similar to the greensand or marl of New Jersey $\S$, and also suggests the probable cretaceous age of certain of the strata on Martha's Vineyard||. In this connection should be mentioned the first discovery and description of

* Bull. No. 82, U. S. Geol. Surv. Correlation Papers-Cretaceous. (1891.)

$\uparrow$ Proc. Acad. Nat. Sci. Phil. xx. 157, 158 (1868).

\$ Am. Journ. Sci. vii. 240-248 (1824).

$\$$ Rept. on the Geol. of Mass., examined under the directlon of the Government of that State during the years 1830 and 1831 (Am. Journ. Sci. xxii. 1-70 (1832).

"Final Rept. on the Geol. of Mass., vol. il. pp. 429, 430, Pl. 19, flgs. 1-5. (1841.) 
fossil leaves and fruit from these strata-a discovery the importance of which we can only appreciate fully in the light of investigations made within the past few years, inasmuch as some of these can now be identifed with well-recognized cretaceous species subsequently found in New Jersey, Staten Island, Long Island and Martha's Vineyard itself. Prominent among Prof. Hitchcock's specimens from the latter locality are certain " pearshaped seeds," in regard to which he says : "It seems to me very obvious that these remains must be the seed ressels of coniferous plants" - an observation which shows a very acute appreciation of their probable affinities, as the same objects have been found abundantly throughout the localities mentioned and have been considered as Dammara or possibly Eucalyptus by more recent investigators, as will be noticed more fully further on.

In 1849 , there appeared an article by M. E. Desor and E. C. Cabot, "On the Tertiary and more recent Deposits in the Island of Nantucket,"* in which they refer to the resemblance between the clay at Sankaty, Nantucket, Truro on Cape Cod and Gay Head, Martha's Vineyard, which are all referred to as probably Tertiary and the conclusion is reached that "Thus the Tertiary cliffs of Gay Head should no longer be looked upon as an isolated fact, but the cliffs of Sancati may be considered as the opposite outcrop of a large tertiary basin, underlying the islands of Nantucket and Martha's Vineyard - . and extending to the south below Long Island and to the north as far as Truro."

In August, 1859, William Stimpson visited Martha's Vineyard and confirmed Prof. Hitchcock's conclusion in regard to the cretaceous age of certain of the stratat, having collected both animal and vegetable remains. The notice in regard to this excursion is, however, very meagre.

At the meeting of the Philadelphia Academy of Natural Sciences on June 2, 1868, E. D. Cope gave an account of his discovery of the fresh-water origin of sands and clays in west New Jersey, on the Delaware River above Camden, which he found to contain leaves of dicotyledonous trees, ctenoid. fish scales and numerous unionidef.

The prosecution of the New Jersey Geological Survey, under Geo. H. Cook, from 1865 to 1887 , with its various reports and maps, gave not only exact descriptions of the cretaceous strata

\footnotetext{
* Quart. Journ. Geol. Soc. London, v. 340-344 (1849).

† "Cretaceous Strata at Gay Head, Mass." (Am. Journ. Sci. xxix, 145 (1860).

$\ddagger$ Proc. Acad. Nat. Sci. Phil. xx. 157-158 (1868).
} 
in New Jersey, but reference to their probable extension through Staten Island and Long Island.

In 1873, a geological map of the United States, prepared by C. H. Hitchcock and W. P. Blake, was published in connection with the Ninth United States Census, On it the nor'th shore of Long Island is shown as cretaceous, in accordance with the views of nearly all who had studied the region. It was criticised, however, by J. D. Dana*, whose ideas in regard to the geology of Long Island have frequently differed from those held by most other authorities, and he advised, as an improvement, "to take away the green color, which means cretaceous, from the whole of the north side of Long Island, no facts making the region cretaceous." Prof. Hitchcock replied briefly to this criticism and gave his reasons for coloring the map to represent cretaceous, in a paper read at the Portland, Me., meeting of the American Association for the Advancement of Science in 1873t, in which he says, "Notwithstanding the evidence is so probable in its favor, it is surprising to observe that mine is the first published map that colors their area correctly."

Professor Dana subsequently modified his criticism $\ddagger$ by referring to the conclusions of Wm. M. Mather, previously quoted, and ending with the brief paragraph, "We understand that. there are recent discoveries which will place Prof. Mather's conclusion on a better foundation." This practically ended any further controversy in regard to the age of the Long Island strata, for evidence of the presence of cretaceous strata along the north shore of the Island began to accumulate and could no longer be ignored. At a meeting of the New York Lyceum of Natural History, January 9, 1871, attention had been called to angiospermous leaf impressions found in a drift bowlder while digging a well at Williamsburg (Brook]yn), Long Islands, wnd at the meeting of the same society on March 23, 1874, similar specimens were shown from Lloyd's Neck|, many miles. further to the eastward on the north shore of the island. Specimens containing dicotyledonous leaves also turned up in other parts of Brooklyn during excavations for various purposes, and some of these fortunately came into the possession of the Long Island Historical Society, thus insuring their preservation, with the facts connected with their discovery.

\footnotetext{
* Am. Journ. Sci. vi. 64-66 (1873).

† Proc. A. A. A. B. xxil. Part 2d, 131-132 (1874).

$\ddagger$ Am. Journ. Seì. vì, 305 (1873).

8 Proc. Lyc. Nat. Hist., 1st Ser., 149, 150 (1871).

॥ Prnc. Lyc. Nat. Hist., 2d Ser., 127 (1874).
} 
The character of the rock was not understood at the time, however, and it was not until a few years subsequently, when specimens were found in situ, in connection with the clays at Glen Cove, a locality between the other two, that their derivation was understood.

On April 4, 1881, N. L. Britton read apaper before the Academy "On the Geology of Richmond County, N. Y.,"* in which the probable eastward extension of the cretaceous strata through Staten and Long Island is mentioned, and on November 7, 1884, Fredk, J. H. Merrill read a paper before the Academy on the geology of Long Islandt, in which he maintains a very conservative attitude in regard to the cretaceous formation. The Exogyra previously mentioned is referred to, and also the leaf-bearing sandstone, but the evidence is considered as too incomplete, and he merely concludes that "The locality at which the strata most resemble the cretaceous beds of New Jersey is at Glen Cove, where the clays already described are probably of this age."

Just previous to this time J.S. Newberry began his studies of the Amboy clay flora, and shortly afterwards, his views were briefly presented before the New York Academy of Sciencest and the Torrey Botanical Club§. Dr. Newberry was the first to correlate these clays with the Dakota group of the west and the Lower Atane beds of Greenland, by means of their fossil floras, and his researches in this direction also enabled him to at once identify the fossil leaves collected about the same time at Glen Cove as identical with those from the Amboy clays, and thus to fix without question the cretaceous age of the strata, and similar further work in the same direction was subsequently performed by R. P. Whitfield for the faunall.

At a meeting of the New York Academy of Sciences, on May 11, 1885, Fredlk. J. H. Merrill gave a description of the beds at Gay Head, Martha's Vineyard, and referred them to the post pliocene or quaternary. $T$

In 1888, a report upon the geology of Martha's Vineyard** apperred, by N. S. Shaler, and in the following year one upon

* Ann. N. Y. Acad. Sci. iii. 161-182 (1882).

† Ann. N. Y. Acad. Sci. iii. 341-364 (1885).

$\ddagger$ Trans. N. Y. Acad. Sci. v. 133-137 (1886).

$\$$ Bull. Torr. Bot. Club, xiii. 33-37 (1886).

॥ Bull. Am. Mrus. Nat. His. ii. Art. viii. 113-116 (1889).

Ti Trans. N. Y. Acad. Sci. iv. 78, 79 (1885).

*** 7th Ann. Rept. U. S. G. S. 297-363 (1888). 
Nantucket*. Cretaceous and tertiary deposits are recognized upon the former, by means of the fossils, but only tertiary and later on the latter. The author also discusses at some length the stratigraphy of each island and the probable changes which have preceded their present conclition.

In 1889, Prof. Shaler published a paper "On the Occurrence of Fossils of the Cretaceous Age on the Island of Martha's Vineyard, Mass.," + in which he discusses the probable origin of the fossils and the dislocation of the beds. The fauna only is described, no flora.

In 1889, David White visited Gardiner's Island, Block Island, Center Island and Martha's Vineyard, and collected a large amount of cretaceous material, especially plantst, which I was kindly permitted to examine during the past winter, and was thus enabled to idenitfy a large number of the species with those which I had previously collected on Long Island and had become familiar with from the cretaceous of Staten Island and New Jersey. These discoveries proved to be of the highest importance, as we were thus enabled to trace the continuity of the cretaceous strata from New Jersey through Staten and Long Islands to Martha's Vineyard, and to demonstrate beyond question that the theory of Mather and subsequent observers in regard to the eastward extension of the cretaceous formation was correct, and that the geological maps of the region should not only show the north shore of Long Island, but also part of Martha's Vineyard as cretaceous\$, and emphasized the probability that certain limited areas of the New England coast could also be referred to that horizon.

The Long Island material upon which this paper is based consists entirely of fossil plants, no animal remains which could be even provisionally referred to the cretaceous having come under my observation. Fortunately, however, many of these plant remains are in such a perfect state of preservation that they may be readily identified with well known cretaceous species, and the age of the strata in which they occur or from which they have been derived can no longer be questioned.

The total number of species, represented in the specimens

* Bull. No. 53, U. S. G. S. (1889).

† Bull. Mus. Comp. Zoôl. xvi. No. 5, 89-97 (1889).

\$ Am. Journ. Scl. sxxix. 93-101 (1890), and Bull. Geol. Soc. Am. i. 554,555 (1890), with comments by Lester F. Ward, J. S. Newberry and F. J. H. Merrill.

S The tro most recently published geological maps of the United States are 1st, by W. J. McGe日, in 5th Ann. Rept. U. S. G. S. (1884), and, 2d, by C. H. Hitehcock, for the Am. Inst. Mining Eng. (1886). In each of these the north shore of Long Island is recognized as cretaceous, but Martha's Vineyard is designated as tertiary and quaternary only. 
which I have collected or have been enabled to examine is about forty. Of these, some are too fragmentary for exact determination, others, require further examination and comparison, and the remainder are such as have been identified satisfactorily with previously described cretaceous species. These latter are the only ones which it is proposed to include in this contribution.

The greater portion of the material was personally collected on or near the shore of Hempsted Harbor, at Glen Cove. The late Dr. John I. Northrop and other collectors also found specimens at the same locality and on the near-by Dosoris island. A few came from Lloyd's Neck and Brooklyn, and the remainder from Northport and Cold Spring Harbor. All, with the exception of a few in the possession of the Long Island Historical Society are now in the geological museum of Columbia College. The specimens from Glen Cove, Northport and Cold Spring Harbor were found in the clays or else intimately associated with them. All the others were found in the drift, in ferruginous clay concretions or sandstones, exactly as I had previously found them to occur in parts of the drift on Staten Island*. These concretions and blocks of sandstone may be found everywhere in the drift to the south of former cretaceous areas. They represent fragments of cretaceous clays and sands which have been torn up by the continental glacier and carried forward in the débris of the moraine, where they have become hardened by the infiltration and oxidation of ferruginous matter or by the accumulation of limonite on the outside. They are so abundant in the drift, wherever this has crossed any cretaceous outcrop, that they must have been known for a long time, but they failed to attract attention until it was noticed that they occasionally contained impressions of leaves and stems of plants, when their derivation became an interesting problem. No such rock as that in which they were found was known to the north of the moraine, and when it began to be appreciated that the leaves contained in them were of dicotyledonous plants the problem became of still greater interest. Dr. Newberry was one of the first to recognize their importance.

In the Proc. N. Y. Lyc. Nat. Hist. 1st Ser. pp. 149, 150, in the account of the meeting of January 9,1871 , the following paragraph occurs :

The President, Dr. J. S. Newberry, exhibited a piece of red sandstone, containing impressions of leaves, found in excavating the foundation for the gas office in Williamsburgh [Long Island]. Thls, he sald,

* "Palæontology of the Cretaceous Formation on Staten Island." (Trans. N. Y. Acad. Sci. xi. 96-103.) 
was a specimen of remarkable interest. In its lithological characters this rock closely resembles the Triassic sundstone so much used in New York for architectural purposes, but it contained numbers of very beautifuliy preserved impressions of angiospermous leaves. No plants of this kind were known to exist during the Trias, or before the Cretaceous; but we know of no such Cretaceous or Tertiary sandstone on the North American Continent. The mass from which this specimen was taken was a bowlder and the ussociated transported blocks were granite, porphyry, greenstone, dolomite, etc., plainly refererable to well-known localities north of New York. But no such sandstone as this was known, and it became a matter of extreme interest to ascertain what was its origin.

Again, at the meeting of March 23, 1874, as reported in the Proceedings, $2 d$ Ser. No. 4 , pp. 126, 127, the matter cnme up in the following form:

The President described a sandstone containing angiospermous leaves very similar in aspect to those of the Raritan and of the Lower Creta. ceous in the far west, which occurs in bowlders at Lloyd's Neck, L. I. This is undoubtedly the same rock with that of the Williamsburgh Gas House, as he was satisfied by comparison. It is totally unlike anything known in this vicinity, and unfortunately, has not yet been found in silu. Whenever it is, some interesting light will be thrown on the whole question. But its presence under these circumstances, points to its existence in place, at some locality not far away.

As previously stated, we have since found it in place at Glen Cove, and can account for other masses on the theory of glacial transportation and subsequent hardening of incoherent cretaceous material. The demonstration of these facts, however, came too late for their appreciation by Dr. Newberry. Our present interpretation of the facts is also of importance, as indicating the former existence of cretaceous strata in localities where their presence was not suspected, or if suspected, could not be demonstrated. By means of similar facts I was first able to trace the extent and positive existence of the cretaceous formation on certain parts of Staten Island, and reasoning from similar premises and facts in Long Island, we must conclude that at least a portion of New York Harbor and the East River to the north of Brooklyn was occupied by cretaceous strata. It is probable that the archæan axis, which extends through Staten Island and thence diagonally across the harbor to New York, with extensions up the river valleys, was the old shore line in this vicinity, as we find it to have been the case elsewhere. Further eastward, there seems to be no question that 
cretaceous strata occupied practically the whole of what is now Long Island Sound, as I have discussed in a previous article.*

At the western end of Long Island, where Brooklyn now is, the extent of cretaceous strata subject to erosion by the glaciers was very limited, and the paucity of such indications need not surprise us. In fact, the discovery of the few fossil leaves which have been made in digging wells and sewers there, may be considered peculiarly fortuitious. While examining the moraine through the Easteru district of Brooklyn, I was particularly impressed with the great number of the characteristic concretions, many of them containing plant remains (lignite and twigs)at the headof the Newtown Creek valley. I can only account for this as due to the material which was eroded in the formation of the valley. Such valleys or inlets are among the most prominent features in the topography of the north shore of the island, and ice action has been advocated by previous observers as their probable cause. Having this theory in mind, the fact above noted is of some significance.

At this part of the island the clays do not appear anywhere in mass, so far as I am imformed. They were probably in such limited amount on the north side, where subjected to glacial action, that they were entirely eroded, while to the south they were deeply covered by the moraine. As we proceed eastward, however, we find the clays out-cropping on the north shore at many localities, though generally much squeezed and contorted by the pressure of the ice sheet, and they are invariably met with on the south side, containing lignite, whenever wells or other excavations have been sunk to a sufficient depth. Throughout the moraine, also, wherever $I$ have examined it, the characteristic concretions and micaceous sandstones are abundant.

Only a beginning has yet been made in the search for plant remains, but now that attention has been called to the matter they are being reported from a number of localities, and specimens are constantly coming to light, and there seems to be no doubt that the entire north shore of the island will present the same story to the searcher, when it has been carefully explored.

In the vicinity of Glen Cove, where the greatest amount of exploration has been personally made, the clays are exposed at the base of steep bluffs fronting the shores. At Carpenter's clay pits, on the west shore of the cove, a fine white clay is found, associated with sandy clay, white sand, gravel and "kaolin" ; all of which are mined for economic purposes. A few

* Trans. N. Y. Acud. Sci. xii. 190-202. 
leaf fragments have been found in the clays, occurring precisely as they may be found in the clays of New Jersey. On the opposite side, and along the shore of the Sound vari-colored clays are to be seen outcropping on the shore and at the base of the bluff. At a point about midway between the mouth of the cove and Glen Cove landing is a stratum containing lignite, pyrite, and a quantity of red ferruginous shale, in which latter the leaf impressions are well preserved. This stratum is uncovered at low tide, and may be traced into the adjoining bluff. The red shale may be here seen in place and be readily obtained. The tides constantly wear away the clay, exposing the shale, and this is torn out by the waves and scattered along the beach. The first specimens were found in this manner, merely as loose fragments on the beach, and it was not until about a year ago that they were traced to their original situation in the clay outerop.

Following is the list of cretaceous species thus far identified :

Magnolia Capellini, Heer.

Pl. VI. f. 6.

This specimen is referred to the species described and figured by Prof. Heer in Phyllites Crétacées du Nebraska, T. III. f. 5, 6, and Flor. Foss. Arct. III. T. XXXIIl. f. 1-4. In the original description of the Nebraska leaf, the base of the leaf is described and figured as obtuse, which characteristic does not seem to be insisted upon in the specimens subsequently identified by the author with the same species from the L. Atane beds of Greenland. With the latter, our specimen is plainly identical.

Locality: Glen Cove, I. I.

Magnolia speciosa, Heer.

Pl. VII. f. 4.

In the Kreide-Flora von Moletein, on PI. VI., VII. and IX.' Prof. Heer figures under this name certain species which so closely resemble the one here figured, that if we are to retain it in the genus Magnolia no separation would seem advisable. I have thought that its affinities might be with Laurus, (See $L$. protecefolia, Lesq. Cret. and Tert. Flor. VIII. 52, 53, PI. III. f: 9, 10 and XVI. f. 6), or with certain forms described under Ficus, (F. Krausiana, Heer, Kreide-Flora von Moletein, 15, Pl. V. f. 3-6), but its general appearance and associations seem to $b_{e}$ 
more in favor of the name here adopted. I an not aware that either of the above species have yet been identified from the New Jersey clays, but the indications are that they are not uncommon on Long Island.

Locality : Glen Cove, L. I.

Liriodendron simplex, Newb.

Pl. V. f. 1-5 and Pl. VII. f. 2, 3.

Under this specific name I have included a variety of forms referable to the one genus. Dr. J. S. Newberry, in his first description of the species, (Ancestors of the Tulip Tree, Bull. Torr. Bot. Club, XIV. 1-7, Pl. IXI., LXII.), called attention to the great variation in this and allied forms ( $L$. primaevum, Newb.; L. semi-alatum, Lesq.; L. Meekii, Heer; Sapotacites retusus, Heer; S. Haydeni, Heer; Leguminosites Marcouanus, Heer; Phyllites obcordatus, Heer, etc.). Subsequently, in the manuscript of the Flora of the Amboy Clays, he decided that the forms originally described by him, under the name Liriodendron simplex, were generically distinct from Liriodendron, and a new genus, Liriodendropsis, was founded, to include them. The species was also split into two groups, the broad forms being called $L$. simplex, and the narrower ones $L$. angustifolius. These latter are represented, in our specimens, by f. 3, Pl. V. Similar forms were also figured by me from Staten Island. (Palæontology of the Cretaceous Formation in Staten Island, Trans. N. Y. Acad. Sci. XI. Pl. II. f. 3 and 6.) The broad forms are by far the commonest, and are indeed the most abundant of all the cretaceous leaves thus far found either on Staten Island or Long Island, and are likewise so reported by Mr. David White from Gay Head, Martha's Vineyard. (Cret. Plants from Martha's Vineyard, Am. Journ. Sci. XXX1X. (1890) 93-101, Pl. II.) Intermediate forms are figured on Pl. V. f. 5 and Pl. VII. f. 3. Until such time as the Flora of the Amboy Clays is published, I have thought it best to retain Dr. Newberry's only published name for these leaves.

All the specimens here figured are from Glen Cove, L. I.

$$
\begin{aligned}
& \text { Sapindus Morrisoni, Lesq. } \\
& \text { Pl. VI. f. } 3 .
\end{aligned}
$$

Reported, also, from Staten Island and Martha's Vineyard. Locality : Glen Cove, L. I. 


\section{Dalbergia Rixkina, Heer.}

Pl. VI. f. $4,5$.

The specimens here figured seem to agree closely with those described and figured by Prof. Heer, under the above name in Flor. Foss. Arct. VI. 102, PI. XXVI. f. 1-3. Our specimens vary considerably in size, and it is possible that we may have more than one species represented. I do not know that it has been previously reported from the eastern United States.

Locality: F. 4. from Tilliamsburg (Brooklyn), I, I.; f. 5 from Lloyd's Neck, L. I.

\section{Diospyros prinieya, Heer.}

Pl. VII. f. 5.

Previously reportcd from New Jersey and Staten Island.

Locality : Glen Cove, L. I.

\section{Laurus Plutonia, Heer. \\ PI. VI. f. 1.}

This species has been identified previously from both New Jersey and Staten Island.

Locality : Glen Cove, L. I.

\section{Sassafras (Araliopsis) acutilobuir, Lesq. \\ PI. VII. f. 1.}

This exceedingly variable species, first described and figured by Prof. Lesquereux (Cret. Flor. VI. 79, Pl. XIV. f. 1, 2,) is well represented in its average shape and size by the specimen here figured. In the Amboy clays it is very abundant, but only this one specimen has as yet turned up on Long Island.

Locality : Glen Cove, L. I.

\section{Myrtophyllum (Eucalyptus ?) Geinttzi, Heer.}

Pl. VI. f. 2.

Previously reported from New Jersey, Staten Island and Martha's Vineyard.

Locality : Glen Cove, L. I. 


\section{MAPS, ETC., USED.}

Geological Map of the United States, publisherl in connection with the 9 th U. S. Census, by C. H. Hiteheock and E. P. Blake.

Geological Map of Now Jersey. Rept. Geol. Surv. of N. J., 1882.

Geological Map of the Vicinity of Now York, by D. S. Martin.

Coast Survey Chart No. VIII. Approaches to New York. Gay Head to Cape Henlopen.

The Ancestors of the Tulip Tree (Plates LXI. and LXIJ. Bull. Torr. Bot. Clul, Jan. 188i) by J. S. Newberry:

Flora Fossilis Aretica, Vols. VI. and VII. (Plates representing the fossil flora of the L. Atane and Patoot beds), by Oswald Heer.

United States Geological Survey, Vol. VI. (Cretaceous Flora), by Leo Lesquereux.

\section{SPECIMENS SHOWN.}

White and colored clays, pyrite nodules and lignite. Glen Cove, L. I.

Plant remains in clay. Northport, L. I.

Plant remains in sandstone, from the drift at Brooklyn, L. I.

Plant remains in concretions, from the drift near Glen Cove, L. I.

Plant remains in red shale, from clay outerop on the shore near Glen Cove, I.

\section{ON ANTENNAE AND OTHER APPENDAGES OF TRI- ARTHRUS BECKII.}

IBY W. D. MATTHEW.

(Plate VIII.)

Among the problems which palæontologists lave in vain tried to solve was, till a few years ago, that of the structure and affinities of the trilobite. In all the vast numbers of these animals which have been found and studied, scarcely any parts have been preserved, other than the dorsal shield and hypostome. The legs, gills, etc., have practically never been shown on any specimen. This is chiefly because of the easy break afforded by the hard, smooth carapace, but, partly also, because of the character of these organs, which seem to have been soft, ensily disjointed, and prone to maceration and decay. The only cases, as far as I know, in which the organs of the under side have been definitely seen and described, are three specimens of Asaphus platycephalus in which a number of legs are preserved 
PLATE V.

Figs. 1-5. Liviodendron simplex, Newb. Glen Cove, Long Island, N. Y. 


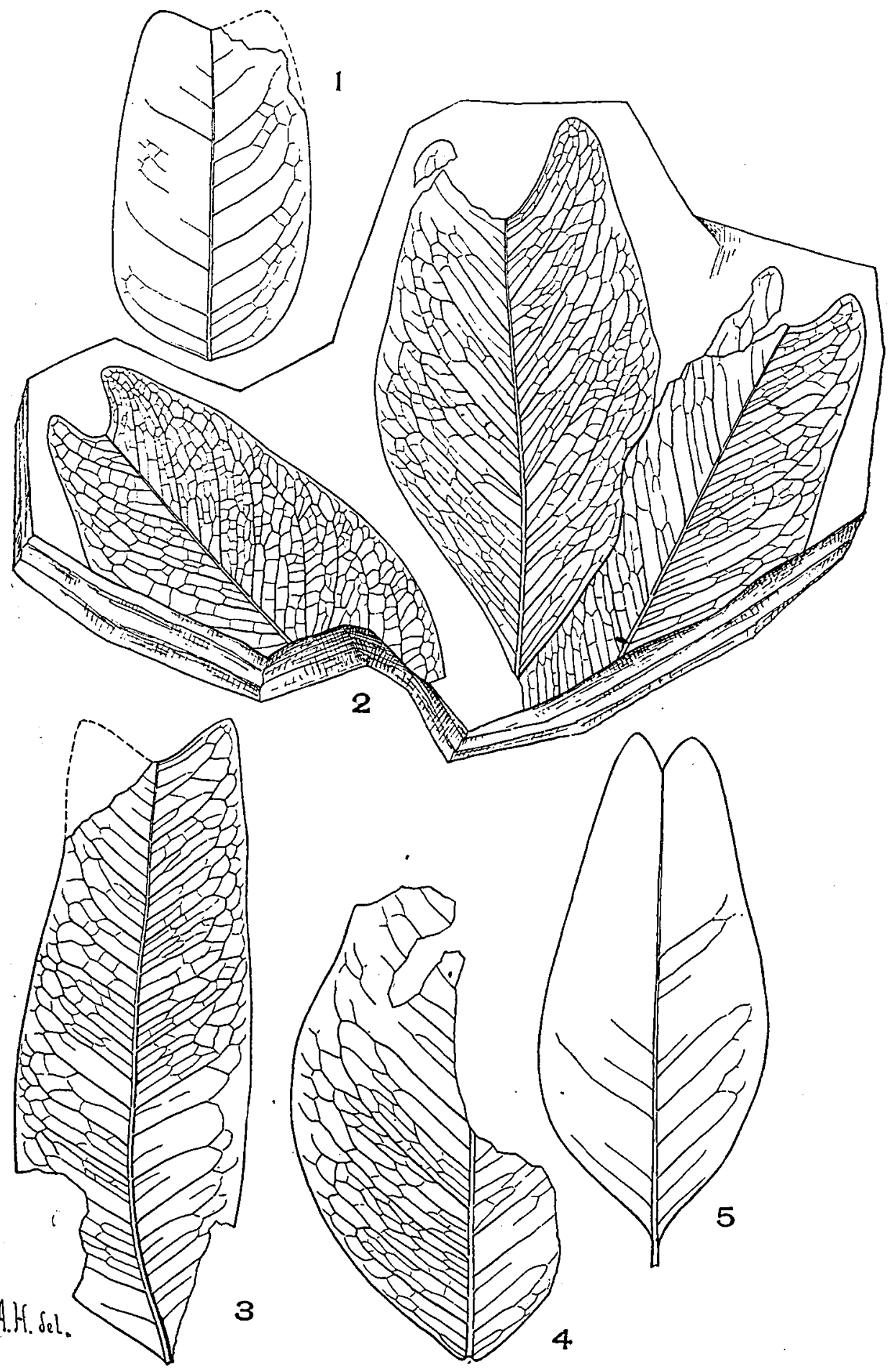

LONG ISLAND CRETACEOUS FLORA. 


\section{PLATE VI.}

Fig. 1. Laurus Plutonia, Heer. Glen Cove, Long Island, New York.

Fig. 2, Myrtophyllum (Eucalyptus?) Geinitzi, Heer. Glen Cove, Long Island, N. Y.

Fig. 3. Sapindus Morrisoni, Lesq. Glen Cove, Long Island, N. Y.

Figs. 4-5. Dalbergia Rinkiana, Heer. No. 4 from Williamsburg (Brooklyn) Long Island, N. Y. No. 5 from Lloyd's Neck, Long Island, $\mathrm{N}$. $\mathrm{Y}$.

Fig. 6. Magnolia Capellini, Heer. Glen Cove, Long Island, N. Y. 
Trans. N. Y. ACAD. SCI.

Vol. XII. Pl. VI.

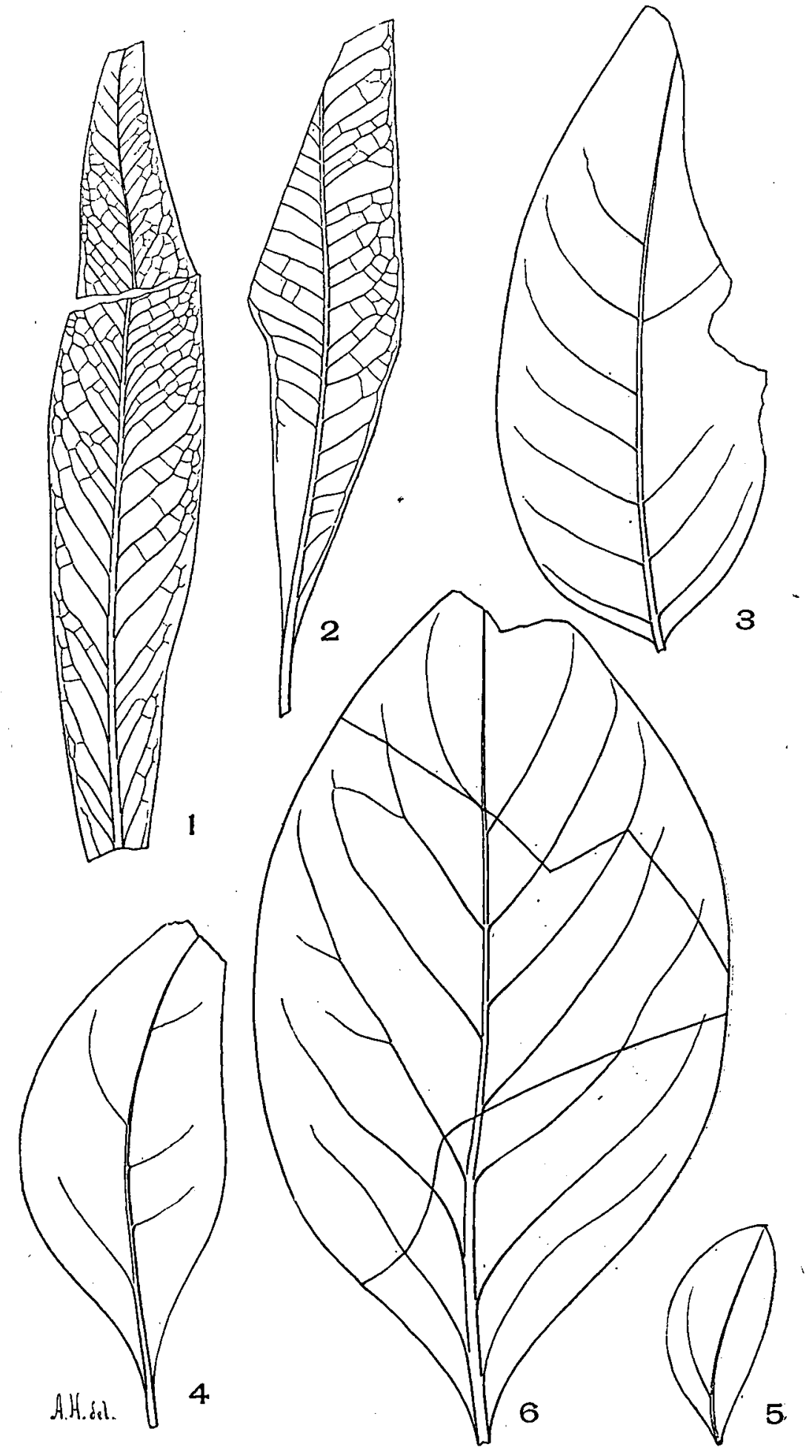

LONG ISLAND URETACEOUS FLORA 


\section{PLATE VII.}

Fig. 1. Sassafras (Araiiopsis) acutilobum, Lesq. Glen Cove, Long Island, N. Y.

Figs. 2-3. Liriodendron simplex, Newb. Glen Cove. Long Island, N. Y.

Fig. 4. Magnolia speciosa, Heer. Glen Cove, Long Island, N. Y.

Fig. 5. Diospyros primava, Heer. Glen Cove, Long Island, N. Y. 


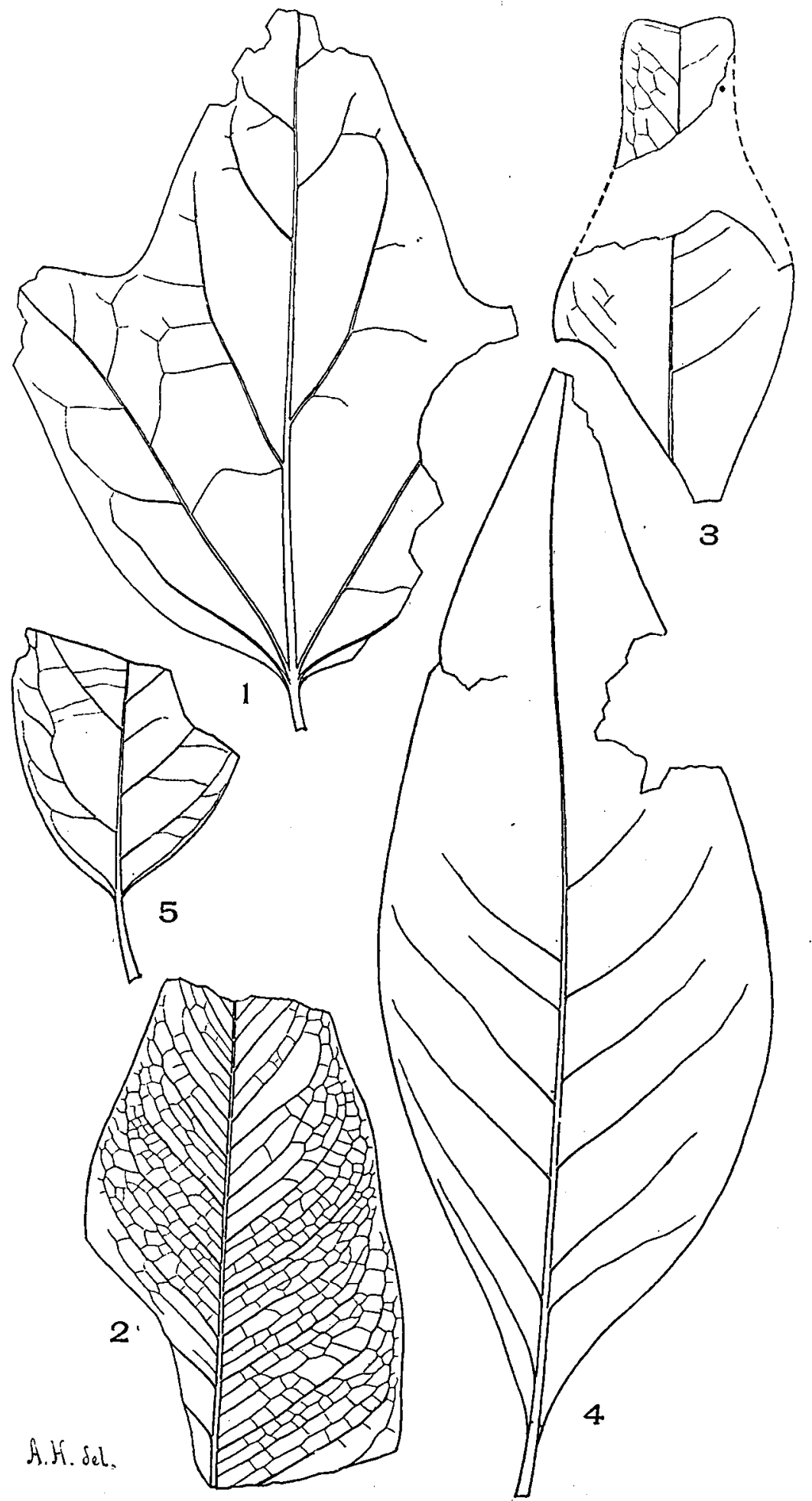

LONG ISLAND CRETACEOUS FLORA. 

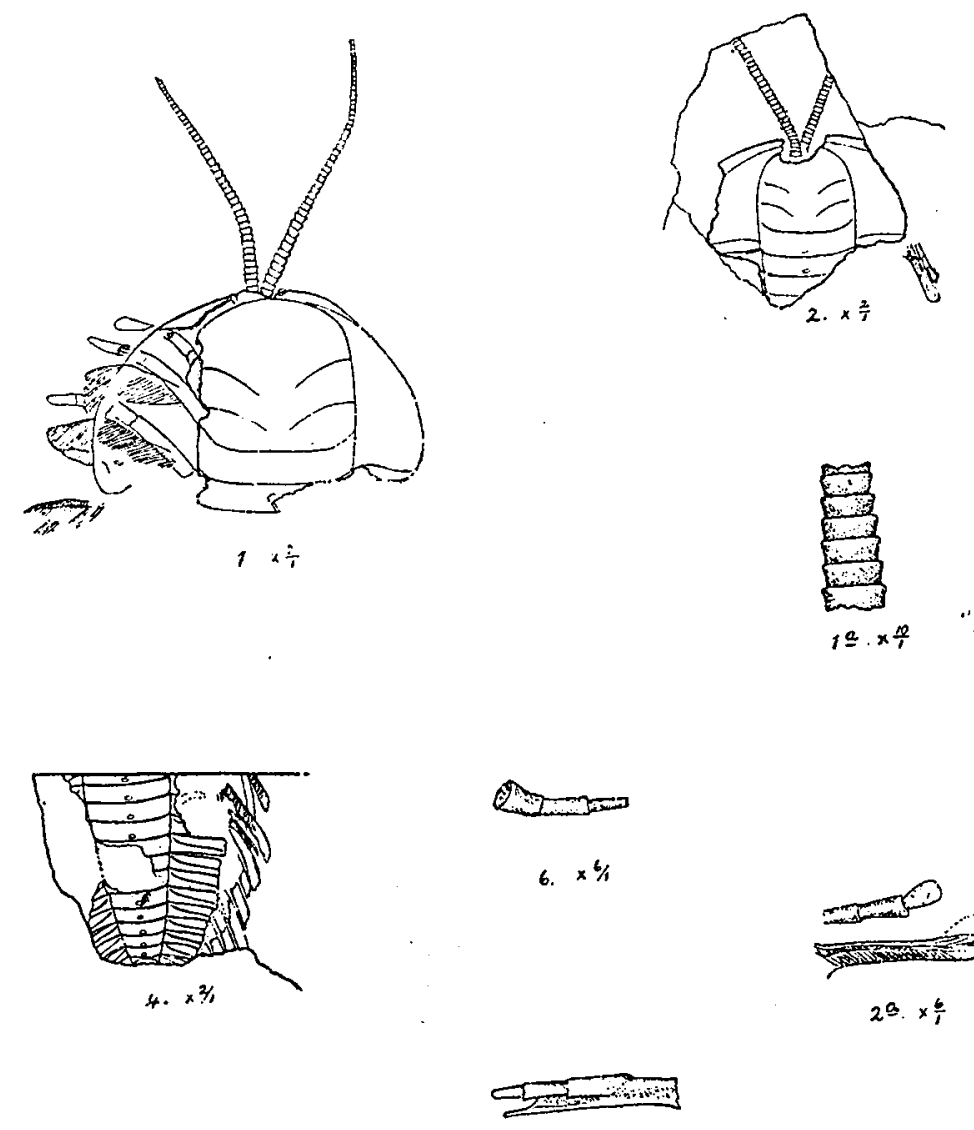

5. $\times 4$
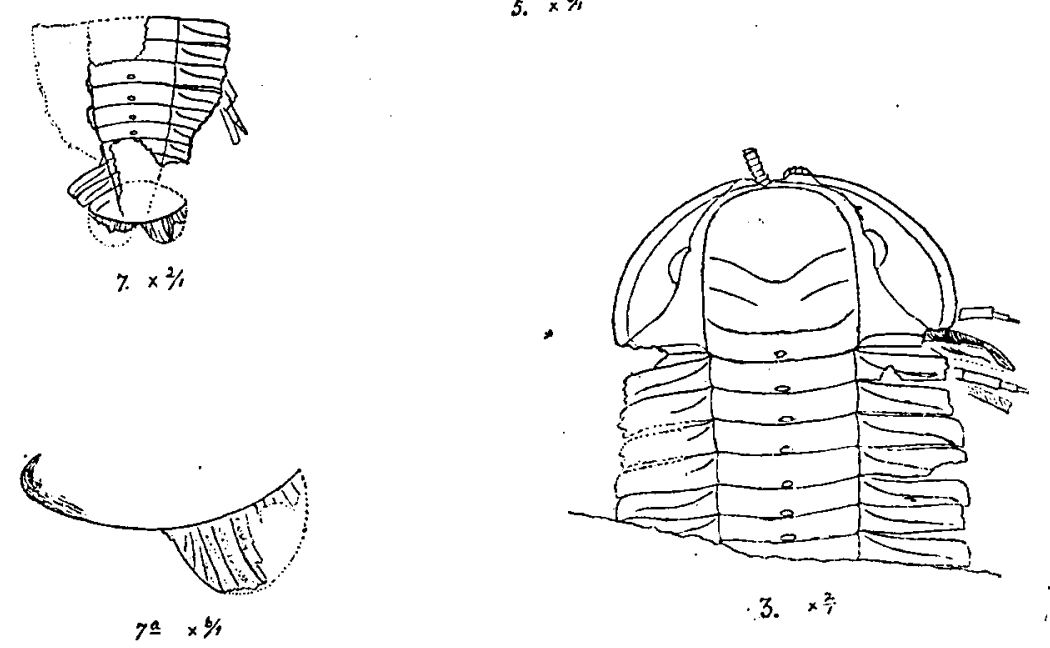